\title{
Respons Siswa SMP terhadap Media Science Comic pada Materi Sistem Ekskresi Manusia
}

\author{
Rizki Indriana Efendi ${ }^{1 *}$, Laila Khamsatul Muharrami ${ }^{1}$, Aida Fikriyah ${ }^{1}$, Nur Qomaria ${ }^{1}$ \\ ${ }^{1}$ Program Studi Pendidikan IPA, Fakultas Ilmu Pendidikan, Universitas Trunojoyo Madura \\ * E-mail: rizkiindriana69@gmail.com
}

\begin{abstract}
Abstrak
Respons siswa merupakan tanggapan dan pendapat siswa terhadap media yang telah dikembangkan dan dinyatakan layak. Media yang telah dikembangkan adalah science comic pada materi sistem ekskresi manusia. Tujuan penelitian ini adalah untuk mendeskripsikan respons siswa SMP terhadap media science comic materi sistem ekskresi manusia. Penelitian yang telah dilaksanakan termasuk ke dalam penelitian deskriptif kuantitatif. Adapun media science comic yang digunakan untuk mengukur seberapa besar respons siswa telah dinyatakan layak dan valid oleh para pakar. Penelitian ini telah dilaksanakan pada siswa SMP kelas VIII di UPTD SMPN 1 Banyuates dan UPTD SMPN 1 Ketapang. Selanjutnya, data yang diperoleh adalah berupa data respons siswa yang diperoleh dari lembar angket respons siswa. Hasil respons siswa menunjukkan bahwa sebesar $80,7 \%$ respons siswa terhadap media science comic pada materi sistem ekskresi manusia yang termasuk dalam kategori baik. Maka dari itu, dapat disimpulkan bahwa media science comic yang telah dikembangkan memperoleh respons yang positif dari siswa.
\end{abstract}

Kata Kunci: media, science comic, respons siswa.

\section{PENDAHULUAN}

Pendidikan sangat penting untuk memperoleh keseimbangan perkembangan setiap individu atau masyarakat (Nurkholis, 2013). Perkembangan Ilmu Pengetahuan dan teknologi sangat berpengaruh pada kehidupan pribadi dan kelompok, misalnya aktivitas, gaya hidup, metode belajar, serta cara berfikir diberbagai bidang termasuk bidang Pendidikan (Stefany, 2015). Perkembangan Ilmu Pengetahuan dan Teknologi semakin mendorong pemanfaatan teknologi baru dalam pembelajaran. Adanya perkembangan Ilmu Pengetahuan dan Teknologi, guru dituntut untuk lebih kreatif dalam mengembangkan media pembelajaran yang menarik dan inovatif (Sandika, 2020). Penggunaan media pembelajaran sangat dianjurkan untuk memaksimalkan guru dalam menyampaikan materi pada siswa (Sumarsono et al., 2019).

Media pembelajaran merupakan suatu alat yang digunakan untuk menyampaikan materi pada peserta didik, sehingga materi yang disampaikan akan lebih mudah dipahami (Asyhari \& Silvia, 2016). Media pembelajaran berfungsi untuk menyalurkan pesan dari guru kepada siswa, sehingga komunikasi antara guru dan siswa lebih efektif dan efisien. Selain itu media pembelajaran 
juga dapat meningkatkan motivasi belajar siswa sehingga siswa lebih semangat dalam proses belajar dan dapat mencapai tujuan pembelajaran dengan baik (Tafonao, 2018). Hal ini diperkuat dengan pernyataan Widiasih (2017), bahwa media pembelajaran dapat meningkatkan motivasi dan hasil belajar siswa pada mata pelajaran ekonomi kelas XI IPS SMA.

Media dikelompokkan bersadarkan sifat, yaitu media auditif, media visual, dan media audio-visual. Media auditif yaitu media yang hanya memiliki unsur suara sehingga hanya bisa didengarkan tanpa dilihat. Media visual yaitu media yang hanya memiliki unsur unsur gambar atau tulisan, sehingga hanya dapat dilihat tanpa bisa mendengarkan. Sedangkan media audio-visual yaitu media yang dapat dilihat dan dapat didengarkan. Media visual salah satunya yaitu media komik yang terdiri dari gambar dan tulisan tidak bergerak (Sanjaya, 2012).

Saputro (2017) menyatakan bahwa media komik adalah suatu media visual dalam dunia Pendidikan yang berfungsi untuk menyampaikan informasi dalam bentuk gambar dan tulisan. Selain itu, berfungsi juga untuk meningkatkan motivasi belajar siswa serta membangkitkan rasa ingin tahu siswa (Listiawati \& Komariyah, 2020). Hal ini sesuai dengan pernyataan Hendarto et al. (2018) yang menyatakan bahwa media komik dapat menciptakan suasana belajar yang menyenangkan serta dapat meningkatkan minat baca siswa karena di desain dengan gambar dan warna yang menarik. Media komik juga dapat memudahkan guru dalam menyampaikan materi saat proses pembelajaran.

Media science comic dapat menjadikan suasana belajaryang menyenangkan. Siswa yang kurang antusias dalam pembelajaran dapat terbantu dengan menggunakan media science comic. Selain itu, media science comic juga mudah dipahami oleh siswa karena disusun dengan Bahasa yang sederhana sesuai dengan Bahasa siswa sehari-hari. Media science comic juga dapat meningkatkan minat baca siswa karena siswa merasa tertarik dengan desain media science comic yang berwarna serta dengan gambar tokoh komik yang unik (Hendarto et al,. 2018).

Hasil respons siswa pada penelitian Purwanto (2013) menunjukkan bahwa respons siswa terhadap media komik sangat baik, dengan persentase $92,7 \%$. Adapun penelitian Minarni et al. (2019) tentang respons siswa terhadap media science comic menunjukkan bahwa respons siswa terhadap media science comic yang digunakan tergolong sangat menarik dengan persentase respons siswa sebesar $84 \%$.

Sedangkan Ambaryani \& Airlanda (2017) menyampaikan bahwa respons siswa terhadap media komik sangat baik dengan persentase 90\%. Pada penelitian yang sudah dilakukan, dapat diketahui bahwa respons siswa terhadap penggunaan media komik dalam pembelajaran mendapatkan respons yang baik. Simanjuntak \& Imelda (2018) menyatakan bahwa respons adalah suatu jawaban atau tanggapan sebagai hasil dari tes atau kuesioner. 
Respons siswa adalah suatu tanggapan atau reaksi dari siswa yang muncul akibat rangsangan. Respons siswa dapat dilihat dengan menggunakan angket (Simanjuntak, 2018). Angket adalah teknik pengumpulan data secara tidak langsung, karena peneliti tidak bertanya secara langsung kepada responden. Angket terdiri dari dua yaitu angket terbuka berisi pernyataan yang diisi secara bebas oleh responden, dan angket tertutup yang dapat diisi sesuai pilihan jawaban yang tersedia (Sukmadinata, 2015).

Berdasarkan silabus Kurikulum 2013 pada kelas VIII terdapat materi sistem ekskresi manusia. Sistem ekskresi manusi amerupakan materi yang bersifat abstrak dan teoritis karena berhubungan dengan proses fisiologi dalam tubuh yang tidak dapat dilihat oleh indera manusia, sehingga semakin sulit dipahami ketika menggunakan buku pegangan berupa buku teks (Saragih dan Tarigan, 2016). Media pembelajaran dapat dijadikan sebagai alternatif untuk mengajak siswa dalam situasi belajar yang menyenangkan, misalnya dengan menggunakan media science comic. Media science comic merupakan alat bantu dalam menyampaikan pesan saat proses pembelajaran yang tersusun atas gambar dan tulisan, serta memiliki sebuah alur cerita. Sehingga siswa tidak bosan pada saat proses pembelajaran.

Berdasarkan paparan tersebut, penelitian tentang respons siswa terhadap media science comic pada materi sistem ekskresimanusia penting untuk dilakukan.

Penelitian ini memiliki rumusan masalah yaitu: Bagaimana respons siswa terhadap media science comic pada materi sistem ekskresi manusia. Adapun tujuan penelitian ini adalah mendeskripsikan respons siswa terhadap media science comic pada materi sistem ekskresi manusia.

\section{METODE}

Jenis penelitian ini yaitu penelitian deskriptif. Pada penelitian ini, yang dideskripsikan adalah respons siswa terhadap media science comic pada materi sistem ekskresi manusia. Penelitian dilakukan di UPTD SMP Negeri 1 Banyuates dan UPTD SMP Negeri 1 Ketapang.

Validator menilai kelayakan media science comic, kelayakan materi science comic, angket respons siswa, dan angket keterbacaan siswa terhadap media science comic. Berdasarkan hasil, validator menyatakan bahwa media science comic pada materi sistem ekskresi manusia telah valid dan layak digunakan tanpa revisi.

Teknik pengumpulan data yaitu dengan angket dan dokumentasi. Angket yaitu teknik pengumpulan data yang dilakukan secara tidak langsung, angket terdiri dari 2 jenis yaitu angket terbuka dan angket tertutup (Sukmadinata, 2015). Angket yang dilakukan pada penelitian ini yaitu angket tertutup, pilihan jawaban sudah tersedia. Sedangkan dokumentasi berfungsi untuk mendokumentasikan penelitian, berisi foto siswa saat mengisi angket, hasil angket, dan hasil validasi ahli.

Angket respons siswa menggunakan angket tertutup dan terdiri atas 20 soal. Skala pada angket respons siswa 
Indonesian Journal of Mathematics and Natural Science Education, 2 (1), 2021

Rizki Indriana Efendi, Laila Khamsatul Muharrami, Aida Fikriyah, Nur Qomaria

menggunakan skala guttman. Kriteria penskoran skala Guttman dapat dilihat pada tabel 1 berikut.

Tabel 1. Penskoran skala Guttman

\begin{tabular}{ccc}
\hline Kriteria & Skor Positif & Skor Negatif \\
\hline Ya & 1 & 0 \\
Tidak & 0 & 1 \\
\hline
\end{tabular}

(Modifikasi dari Sulistyaningrum, 2017)

Tahapan penelitian yang dilakukan sebagai berikut:

a. Menyebarkan media science comic dan angket respons kepada siswa.

b. Memeriksa dan menghitung skor dari setiap jawaban yang dipilih oleh siswa pada angket yang diberikan.

c. Merekapitulasi skor yang diperoleh dari setiap indikator menggunakan skor berdasarkan tabel 1.

d. Menghitung skor yang diperoleh dengan menggunakan persamaan 1 berikut.

e. Hasil perhitungan skor dilihat pada tabel 2, untuk menentukan hasil respons siswa termasuk kategori menarik sampai kategori kurang menarik.

$\%$ Respons $=\frac{S p}{S m} \times 100 \%$

Sp = Skor yang diperoleh

$\mathrm{Sm} \quad=$ Skor maksimal

Tabel 2. Kriteria respons

\begin{tabular}{cc}
\hline $\begin{array}{c}\text { Persentase respons } \\
\text { siswa }\end{array}$ & Keterangan \\
\hline $75<\mathrm{X} \leq 100$ & Menarik \\
$50<\mathrm{X} \leq 75$ & Cukup Menarik \\
$25<\mathrm{X} \leq 50$ & Kurang Menarik \\
$0<\mathrm{X} \leq 25$ & Tidak Menarik \\
\hline
\end{tabular}

(Dimodifikasi dari Prasetiyo, 2017)

\section{HASIL DAN PEMBAHASAN}

Angket respons siswa merupakan tanggapan siswa terhadap media science comic yang telah dikembangkan dan diujicobakan pada siswa SMP kelas VIII pada materi sistem ekskresi manusia. Uji coba dilakukan secara terbatas, yaitu pada 2 sekolah yaitu UPTD SMP Negeri 1 Banyuates dan UPTD SMP Negeri 1 Ketapang dengan total responden 10 siswa. Siswa diberikan media science comic lalu diminta untuk mengisi angket respons tertutup. Indikator angket respons siswa dapat dilihat pada tabel 3 berikut.

Tabel 3. Indikator angket respons siswa

\begin{tabular}{cc}
\hline No & Indikator \\
\hline 1 & Menunjukkan ketertarikan siswa \\
2 & Manfaat science comic dalam pembelajaran \\
3 & Kesesuaian media science comic sebagai \\
\multicolumn{2}{c}{ media pembelajaran } \\
\hline
\end{tabular}

Angket respons siswa diberikan pada siswa SMP kelas VIII setelah media science comic diterapkan. Angket respons siswa berfungsi untuk mengetahui respons atau tanggapan siswa terhadap media science comic yang digunakan. Angket yang diberikan berisi 10 pertanyaan positif dan 10 pertanyaan negatif dengan jenis angket tertutup, yaitu jawaban sudah tersedia pada angket sehingga siswa dapat memilih jawaban yang sudah tersedia, hal ini dilakukan agar peneliti lebih mudah dalam proses menganalisis data. Rata-rata angket respons siswa dapat dilihat pada tabel 4.

Aspek angket respons siswa yang pertama yaitu aspek ketertarikan siswa. Berdasarkan hasil analisis angket respons siswa diperoleh persentase 
Tabel 4. Rata-rata hasil angket respons siswa

\begin{tabular}{|c|c|c|c|c|c|}
\hline No & Aspek Penilaian & No. Soal & Hasil (\%) & $\begin{array}{c}\text { Rata-rata } \\
(\%)\end{array}$ & Kategori \\
\hline 1. & $\begin{array}{l}\text { Meningkatkan ket- } \\
\text { ertarikan siswa }\end{array}$ & $\begin{array}{c}1(+) \\
2(+) \\
3(+) \\
5(-) \\
6(-) \\
11(-)\end{array}$ & $\begin{array}{c}100 \\
90 \\
100 \\
90 \\
60 \\
80\end{array}$ & 86,6 & Baik \\
\hline 2. & $\begin{array}{l}\text { Manfaat media sci- } \\
\text { ence comic dalam } \\
\text { pembelajaran }\end{array}$ & $\begin{array}{c}4(+) \\
7(+) \\
8(-) \\
9(-) \\
10(+) \\
12(+) \\
13(-) \\
14(+) \\
15(-) \\
16(-)\end{array}$ & $\begin{array}{l}80 \\
30 \\
90 \\
30 \\
90 \\
80 \\
60 \\
70 \\
50 \\
50\end{array}$ & 63 & $\begin{array}{l}\text { Cukup } \\
\text { Baik }\end{array}$ \\
\hline 3. & $\begin{array}{l}\text { Kesesuaian } \\
\text { Media science com- } \\
\text { ic sebagai media } \\
\text { pembelajaran }\end{array}$ & $\begin{array}{l}17(+) \\
18(-) \\
19(+) \\
20(-)\end{array}$ & $\begin{array}{c}100 \\
80 \\
90 \\
100\end{array}$ & 92,5 & Baik \\
\hline & Persentase Total & & & 80,7 & Baik \\
\hline
\end{tabular}

aspek ketertarikan siswa sebesar 86,7\% dengan kategori sangat menarik. Aspek ketertarikan siswa yaitu penilaian yang terkait dengan desain dan isi science comic menarik atau tidak bagi siswa.

Perolehan persentase pada aspek pertama cukup tinggi karena media science comic yang dikembangkan memiliki desain tokoh yang sesuai dengan materi sistem ekskresi manusia, warna, background yang menarik bagi siswa. Hal ini sesuai dengan pernyataan Nurlatipah et al. (2015) yang menyatakan bahwa media komik sangat menarik bagi siswa dan dapat digunakan sebagai media pembelajaran dengan persentase respons sebesar $85,12 \%$ dengan kategori sangat baik.

Aspekangket respons yang kedua yaitu aspek manfaat media science comic dalam pembelajaran. Berdasarkan hasil analisis angket respons siswa diperoleh persentase aspek kedua yaitu sebesar 63\% dengan kategori cukup menarik. Hal ini sesuai dengan penelitian Kurniawati et al. (2017) media science comic dapat merangsang aktivitas belajar siswa serta memberikan pengalaman belajar yang bermakna. Aspek kedua ini berisi penilaian terkait manfaat yang dirasakan siswa dalam menggunakan science comic saat proses pembelajaran. Perolehan persentase respons siswa ini cukup rendah karena media science comic hanya diterapkan satu kali, sehingga siswa kurang merasakan manfaat dari media science comic yang diigunakan.

Aspek angket respons yang ketiga yaitu aspek kesesuaian media science comic sebagai media pembelajaran. Berdasarkan hasil analisis angket respons siswa diperoleh persentase sebesar 92,5\% dengan kategori sangat menarik. Aspek 
ketiga ini berisi tentang kesesuaian tokoh, dialog, serta ilustrasi dengan materi sistem ekskresi manusia.

Perolehan persentase pada aspek ketiga ini cukup tinggi, karena gambargambar organ serta proses pembentukan urin pada media science comic yang dikembangkan sudah sesuai dengan materi sistem ekskresi manusia. Maryani dan Amalia (2018), menyatakan bahwa penggunaan media komik dalam proses pembelajaran sangat cocok serta dapat menjadikan proses belajar yang efektif dan meningkatkan minat baca siswa.

Hal ini sesuai dengan teori belajar perkembangan kognitif yang dikemukakan oleh Jean Piaget yaitu siswa dapat membangun sendiri pemahamannya melalui pengalaman belajar yang menyenangkan. Berdasarkan analisis respons siswa diperoleh rata-rata hasil respons siswa sebesar 80,7\% dengan kriteria menarik.

\section{SIMPULAN}

Berdasarkan hasil penelitian dapat disimpulkan bahwa respons siswa terhadap media science comic pada materi sistem ekskresi manusia di kelas VIII SMP termasuk baik, dengan rata-rata respons siswa sebesar $80,7 \%$.

\section{DAFTAR PUSTAKA}

Ambaryani, \& Airlanda, G. S. (2017). Pengembangan Media Komik untuk Effektifitas dan Meningkatkan Hasil Belajar Kognitif Materi Perubahan Lingkungan Fisik. Jurnal Pendidikan Surya Edukasi, 3 (1), 19-28.

Ariyawati, P. A. M., Waluyo, J., \& Prihatin, J. (2017). Analisis Respons Siswa Terhadap Model Pairs, Invertigation and Communication (PIC) dalam
Pembelajaran IPA. Jurnal Pembelajaran Dan Pendidikan Sains, 2 (1), 9-15.

Asyhari, A., \& Silvia, H. (2016). Pengembangan Media Pembelajaran Berupa Buletin dalam Bentuk Buku Saku Untuk Pembelajaran IPA Terpadu. Jurnal Ilmiah Pendidikan Fisika Al-BiRuNi, 05(April), 1-13.

Hendarto, P., Maridi, \& Prayitno, B. A. (2018). Keefektifan Modul Berbasis Guided Inquiry dilengkapi Komik terhadap Kemampuan Berargumentasi ditinjau dari Minat Baca Siswa. Jurnal Pendidikan, Volume 3(Nomor 12), 1652-1663.

Kurniawati, A. A., Wahyuni, S., \& Putra, P. D. A. (2017). Utilizing of Comic and Jember' $s$ Local Wisdom as Integrated Science Learning Materials. International Journal of Social Science and Humanity, 7(1), 47-50. https://doi. org/10.18178/ijssh.2017.7.1.793

Lestari, D. I., \& Projosantoso, A. K. (2016). Pengembangan Media Komik IPA Model PBL untuk Meningkatkan Kemampuan Berfikir Analitis dan Sikap Ilmiah Developing Science Comic Media Using the ProblemBased Learning Model to Increase the Analytical Thinking Ability and Scientific Attitude. Jurnal Inovasi Pendidikan IPA, 2(2), 145-155.

Maryani, I., \& Amalia, L. (2018). The Development of Science Comic Book to Improve Strudent's Understanding in Elementary School. Jurnal Inovasi Pendidikan IPA, 4(1), 75-82.

Nurkholis. (2013). Pendidikan dalam Upaya Memajukan Teknologi. Jurnal Kependidikan, 1(1),24-44.

Nurlatipah, N.,Juanda,A.,\&Maryuningsih, Y. (2015). Pengembangan Media Pembelajaran Komik Sains yang Disertai Foto untuk Meningkatkan Hasil Belajar Siswa kelas VII SMPN 2 Sumber pada pokok Bahasan Ekosistem. Jurnal Scientiae Educatia, $5(2)$.

Purwanto, D. (2013). Pengembangan Media KOmik IPA Terpadu Tema Pencemaran Air Sebagai Media Pembelajaran untuk Siswa Kelas VII. 
Jurnal Pendidikan Sains, 1(1), 71-76.

Sanjaya, W. (2012). Perencanaan dan Desain Sistem Pembelajaran. Kencana.

Saputro, A. D. (2017). Peran Media Pembelajaran Komik Sains dalam Meningkatkan Prestasi Belajar Siswa di Pendidikan Dasar. Journal For Islamic Social Sciences, Volume 2(Nomor 1), $61-72$.

Saragih, L. E., \& Tarigan, R. (2016). Perbedaan Hasil Belajar Siswa dengan Menggunakan Model Pembelajaran Kooperatif Script dan Problem Human Excretory System Subject. Jurnal Pelita Pendidikan, 4(2), 148-152.

Simanjuntak, S. D., \& Imelda. (2018). Respons Siswa Terhadap Pembelajaran Matematika Realistik Dengan Konteks Budaya Batak Toba. Journal of Mathematics Education and Science, 4(1), 81-88.

Sumarsono, Adi., Anisah., \& Iswahyuni. (2019). Media Interaktif Sebagai Optimalisasi Pemahaman Materi Permainan Bola Tangan. Jurnal Pendidikan Jasmani Indonesia. 15(1), 1-11.

Stefany, E. M. (2015). Respons Siswa Pada Pengembangan Media Pembelajaran : Implementasi Pada Mata Pelajaran TIK Kelas VIII Di SMP Negeri 4 Denpasar. Jurnal Ilmiah Edutic, 2(2), 1-6.

Sukmadinata, N. . (2015). Metode Penelitian Pendidikan. PT Remaja Rosdakarya.

Sulistyaningrum, D. A. (2017). Pengembangan Quantum Teaching Berbasis Video pembelajaran Camtasia Pada Materi Permukaan Bumi dan Cuaca. Jurnal Pendidikan Dasar, 4(2), 154-166.

Tafonao, Talizaro. 92018). Peranan Media Pembelajaran Dalam Meningkatkan Minat Belajar Mahasiswa. Jurnal Komunikasi Pendidikan, 2(2), 103-114.

Widiasih, Rita., Widodo, Joko., \& Kartini, Titin. (2017). Pengaruh Penggunaan Media bervariasi dan Motivasi Belajar terhadap Hasil Belajar Mata Pelajaran Ekonomi Siswa Kelas XI IPS SMA Negeri 2 Jember Tahun Pelajaran 2016/2017. Jurnal Pendidikan Ekonomi.
11(2), 103-107.

Listiawati, E., \& Komariyah, N. (2020). Pengembangan Media Pembelajaran Video Bus Math (Business Mathematic) Pada Materi Barisan dan Deret. Indonesian Journal of Mathematics and Natural Sciences Education, Vol. 2(1), 136-149.

Sandika, B. (2020). Identification of Students' Misconception in The Topic of Population using FourTier Diagnostic Test. Jurnal Inovasi Pembelajaran Biologi, 1 (1), 19-23.

\section{PROFIL SINGKAT}

Rizki Indriana Efendi merupakan mahasiswa Prodi Pendidikan IPA Universitas Trunojoyo Madura angkatan 2016 dan telah menyelesaikan studi pada 2020.

Laila Khamsatul Muharrami adalah dosen Prodi Pendidikan IPA Universitas TrunojoyoMadurabidanganalisissenyawa kimia. Menyelesaikan pendidikan S1 di Institut Teknologi Sepuluh November tahun 2006 dan pendidikan S2 pada tahun 2008 di universitas yang sama.

Aida Fikriyah merupakan dosen Prodi Pendidikan IPA Universitas Trunojoyo Madura bidang media pembelajaran. Menyelesaikan pendidikan strata 1 pada tahun 2013 sedangkan strata 2 pada tahun 2016 pada universitas yang sama.

Nur Qomaria merupakan dosen Prodi Pendidikan IPA Universitas Trunojoyo Madura bidang evaluasi pembelajaran. Pendidikan strata 1 atau sarjana diselesaikan pada tahun 2010 di Universitas Negeri malang, sedangkan strata 2 atau magister diselesaikan pada tahun 2014 di Universitas yang sama. 